Type of the Paper (Article, Review, Communication, etc.)

\title{
An adaptive controller for DSTATCOM for Power Quality Improvement in distribution system
}

\author{
Atma Ram ${ }^{1}$, Parsh Ram Sharma ${ }^{1, *}$ and Rajesh Kr Ahuja 1,* \\ 1 Faculty of Electrical Engineering \\ J.C. Bose UST, YMCA, Faridabad, Haryana, INDIA, 121006; jcboseust.ac.in \\ Correspondence: e- atmaram@jcboseust.ac.in, atma.ram12@gmail.com Tel.: +91-9467-959-798(F.L.)
}

\begin{abstract}
An adaptive control technique has been implemented for DSTATCOM for power quality enhancement in three phase four wires $(3 \mathrm{P} 4 \mathrm{~W})$ distribution system. The reference source currents are extracted from active components of load current for each phase by using this technique. It has also been used for load balancing, harmonic suppression, power factor improvement and reactive power compensation in distribution system. The adaptive control technique has been tested at varying load in steady state and dynamic conditions. This technique is developed using MATLAB/Simulink and source side harmonics are mitigated under different load conditions which are acceptable in accordance with IEEE standard.
\end{abstract}

Keywords: Linear/nonlinear load; power quality; four leg VSC; neutral current compensation.

\section{Introduction}

With the introduction of power electronics-based load like UPS, TV, LED, variable speed derives etc. which introduce nonlinearity in distribution system and creates harmonics and DC offsets in the system [1]. Two type of power quality problems are arising in distribution system like current related power quality and voltage related power quality problems. For mitigation of these problems in distribution system the custom power devices are used. To mitigate the current related power quality problems the device DSTATCOM is used in distribution system which is a shunt connected CPD [2]. For enhancement of quality of supplied power by AC lines, by using reference current compensation, the various technique for DSTATCOM has been implemented [3,4]. It is so essential to learn the performance of DSTATCOM at different frequency [5]. In small scale generation as well as renewal energy resources the active shunt filters are used in distribution system [6-8]. The shunt compensating devices are used for above discussed application and their performance depends upon the control technique and procedure. Frequency and time domain control technique for DSTATCOM has been presented based on IRPT, SRF etc [9]. For control of shunt active filters, the ANN technique is used. It is further categorized as hidden layer, compressive learning, adaptive neural networkbased learning [10]. Performance of these technique depends upon the learning rate and operating conditions [11]. A least square adaptive control technique has been presented for calculation of in phase components of instantaneous power and regulation of DC link voltage of shunt connected active power device [12]. For harmonics elimination the commonly used adaptive control techniques like digital frequency control, time effective adaptive control and notch filter-based control has been presented in [13-17]. Three different adaptive control technique for DSTATCOM in distribution system has been implemented for power qualities issues mitigation [18]. For computation of essential load current without using the Voltage Controlled Oscillator (VCO) less PLL for three phases to two phases transformation has been implemented [19]. For VSC based DSTATCOM nonlinear adaptive second order Volterra filter (NLVF) has been executed for compensating current injection in distribution system for power quality enhancement [20]. Harmonics as well reactive power compensation using optimal step least square control technique for DSTATCOM for linear/nonlinear load has been presented in [21]. LMS-LMF based control technique for DSTATCOM has been presented for generation of reference supply currents [22]. Integration of Battery energy storage 
system with grid through DSTATCOM for supply /storage of active power to grid/from grid has been implement with SRFT control algorithm for PQ enhancement of grid system [23]. The NN with CGBP (Conjugate back propagation) using $I \cos \varnothing$ technique has been presented for various power problems mitigations [24]. The ANN (artificial Neural Network) technique based on HNN for control of DSTATCOM has been presented for different power related issues mitigations in distribution system [25].

In this paper the adaptive control technique for VSC based four legs DSTATCOM has been developed for regulation of DC link voltage, harmonics suppression of source current, load balancing and neutral current compensation in three phase four wire distribution system.

\section{Proposed system and Control Method}

The distribution system with nonlinear load and three phase four wire DSTATCOM is depicted in figure1. The Rs and Ls represent the source resistance and inductance respectively. For the ripple reduction from DSTATCOM output currents are passed through Lf coupling inductor which connected as shown in figure1.The harmonics of load currents are reduced by injected the DSTATCOM output current. Data for proposed system are presented in table 1.

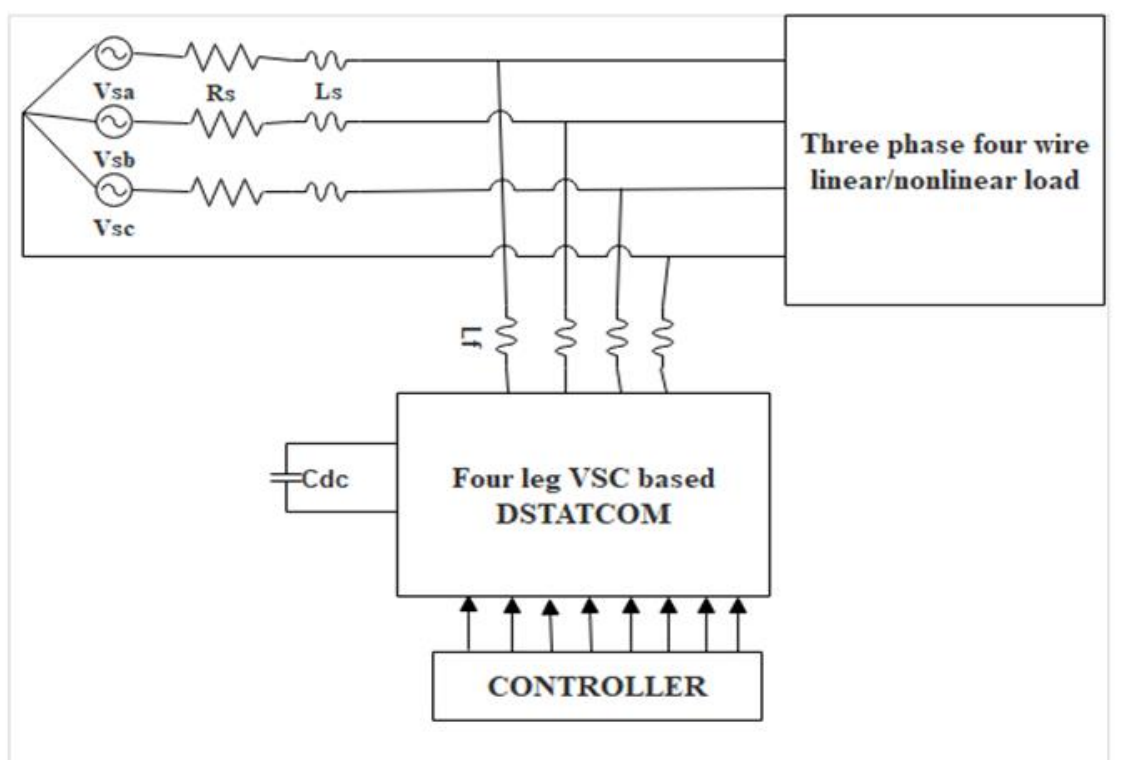

(a)

Figure 1. Proposed Distribution system model

Table 1. Data for simulation of proposed system

\begin{tabular}{ccc}
\hline Sr.no. & Parameters & value \\
\hline 1. & Three phase source voltage(L-L) & $130 \mathrm{~V}, 50 \mathrm{~Hz}$ \\
2. & Source Resistance Rs and & $0.2 \Omega, 2 \mathrm{mH}$ \\
& Inductance Ls & \\
3. & three-phase bridge rectifier non- & $\mathrm{R}=15 \Omega, \mathrm{L}=200 \mathrm{mH}$ \\
4. & linear load & \\
5. & Three phase linear load & $4 \mathrm{kVA}, 0.8$ pf. Lagging. \\
6. & Coupling Inductor & $2.75 \mathrm{mH}$ \\
\hline
\end{tabular}

\subsection{Proposed control method}

Research Control technique developed in this paper is depicted in figgure2.The basic mathematical equations for the extraction of supply reference current are given below. 


\subsubsection{In phase templates calculation}

The $\left(V_{P C C}\right)$ voltage of coupling point is computed as

$$
V_{P C C}=\left(\frac{2}{3}\left(V_{s a}^{2}+V_{s b}^{2}+V_{s c}^{2}\right)\right)^{1 / 2}
$$

Where $\mathrm{V}_{\mathrm{sa}}, \mathrm{V}_{\mathrm{sb}}$ and $\mathrm{V}_{\mathrm{sc}}$ are voltages of phases $\mathrm{a}, \mathrm{b}$ and $\mathrm{c}$ respectively at coupling point. The inphase templates of these voltage are computed by following formulations

$$
U_{s a p}=\frac{V_{s a}}{V_{p c c}}, U_{s b p}=\frac{V_{s b}}{V_{p c c}}, U_{s c p}=\frac{V_{s c}}{V_{p c c}}
$$

\subsubsection{Computation of total active component of load current from distorted load current}

The active current, several harmonic components and DC component are present in distorted load current. From active component of load current this distorted load current is subtracted for current error generation and this error current is multiplied with phase voltage $V_{s a}$ of supply and pass through LPF (low pass filter) and integrated and multiplied with voltage $V_{s a}$, which is in phase of this. By this manner a phase load current active component is computed. For estimation maximum value of active current, it is multiplied by a gain $(\mathrm{k})$, and represent as $I_{L p a}$. The remaining two-phase current $I_{L p b}$ and $I_{L p c}$ are computed using same procedure. Load current average value of (ILAP) is computed as

$$
I_{L A P}=\left(\frac{I_{L p a}+I_{L p b}+I_{L p c}}{3}\right)
$$

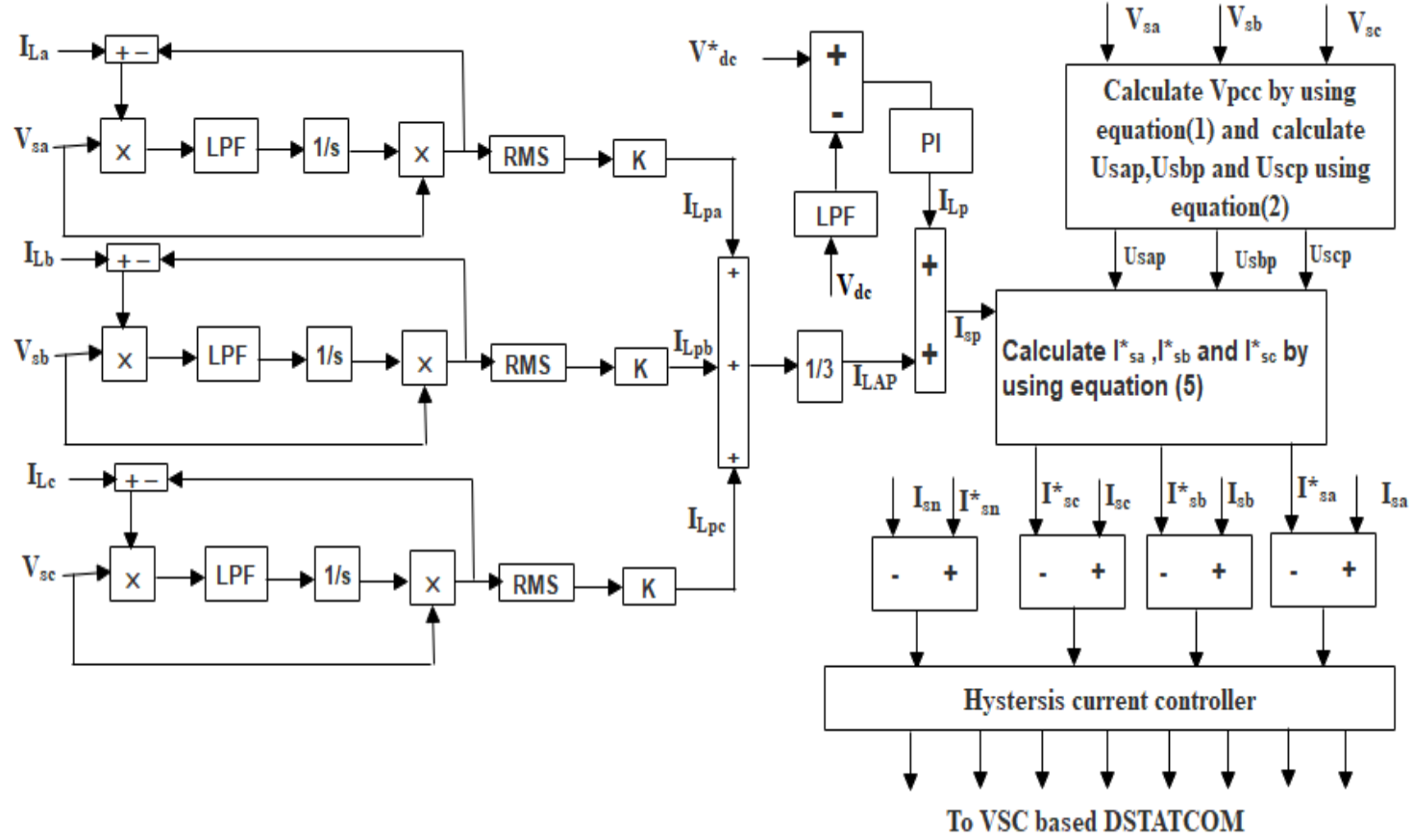

Figure 1. Extraction of reference source current.

2.1.3. Total active component of reference supply current

Total active component of supply current reference $I_{s p}$ is considered as sum of load current average value $\left(I_{L A P}\right)$ and output current of dc bus (PI) regulator $\left(I_{L P}\right)$ and computed as

$$
I_{s p}=I_{L p}+I_{L A P}
$$

2.1.4. Generation of reference supply current and gating signal

Three phase supply current references are calculated as

$$
I_{s a}^{*}=I_{s p} \times U_{s a p}, I_{s b}^{*}=I_{s p} \times U_{s b p}, I_{s c}^{*}=I_{s p} \times U_{s c p}
$$

Three supply currents are added for reference current generation for Fourth leg and denoted as $I_{s n}$ neutral current at supply and given by

$$
I_{s n}=-\left(I_{s a}+I_{s b}+I_{s c}\right)
$$

Reference supply currents are subtracted from supply currents and error signal is given to hysteresis controller for generation of gating signal for VSC based DSTATCOM. This source neutral 
current $\left(I_{s n}\right)$ is subtracted from reference neutral current $\left(I_{s n}^{*}\right)$ and error signal is given to hysteresis controller for generation of gating signal for fourth leg. $I_{s n}^{*} \quad$ current is considered as zero.

\section{Simulation and Results}

An adaptive controller for four -legs VSC based DSTATCOM has been developed and simulated in MATLAB/simulink for distribution system power quality enhancement. The performance of DSTATCOM has been studied in time domain with linear/nonlinear loads for steady state (STC) and dynamic condition.

\subsection{DSTATCOM performance under STC.}

\subsubsection{Linear load}

DSTATCOM performance under steady state with linear load $(4 \mathrm{kVA}, 0.8)$ is depicted in figure3 in terms of PCC voltage $\left(V_{S}\right)$, source current $\left(I_{s a b c}\right)$, load current $\left(I_{L a b c}\right)$ source neutral current $\left(I_{S n}\right)$, load neutral current $\left(I_{L n}\right)$, compensator neutral current $\left(I_{C n}\right)$, DC link voltage $\left(V_{d c}\right)$ and power factor $(P F)$ respectively. Source current is balanced and sinusoidal with linear load.

\subsubsection{Non-linear load}

DSTATCOM performance under steady state with non-linear load (based non-linear load $\mathrm{R}=15 \Omega$ and $\mathrm{L}=100 \mathrm{mH})$ is depicted in figure4 in terms of PCC voltage $\left(V_{s}\right)$, source current $\left(I_{s a b c}\right)$, load current $\left(I_{\text {Labc }}\right)$ source neutral current $\left(I_{S n}\right)$, load neutral current $\left(I_{L n}\right)$, compensator neutral current $\left(I_{C n}\right)$, DC link voltage $\left(V_{d c}\right)$ and power factor $(P F)$ respectively. Source current is balanced and sinusoidal with non-linear load. THD of source current $\left(I_{s a}\right)$ and load current $\left(I_{L a}\right)$ is depicted in figure $5(\mathrm{a}, \mathrm{b})$. The load current has THD 28.76\% whereas source current has only $2.20 \%$ THD which shows the DSTATCOM with adaptive control works efficiently for harmonics suppression for source current.
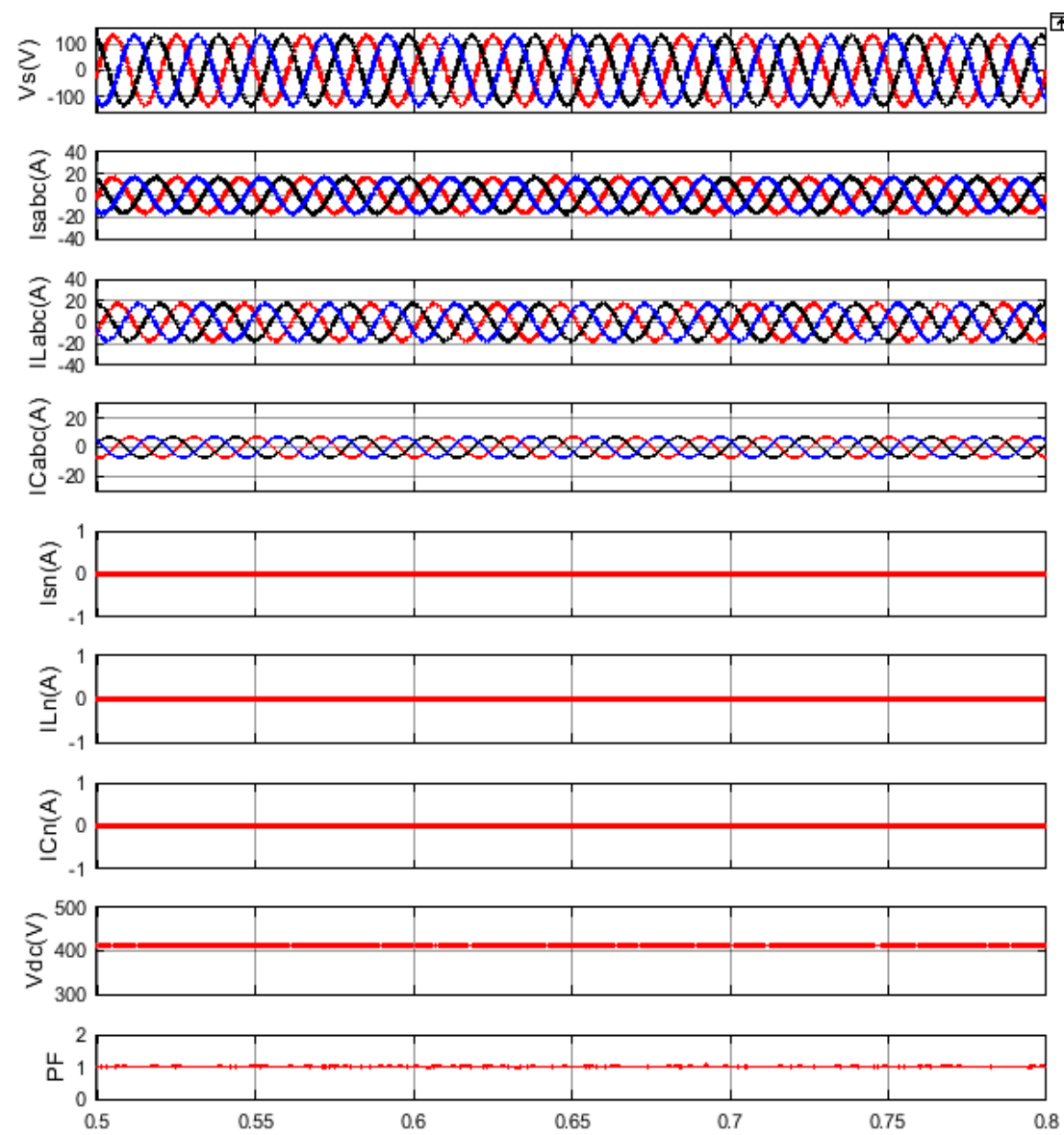

Figure 3. DSTATCOM behavior under balanced linear load condition 

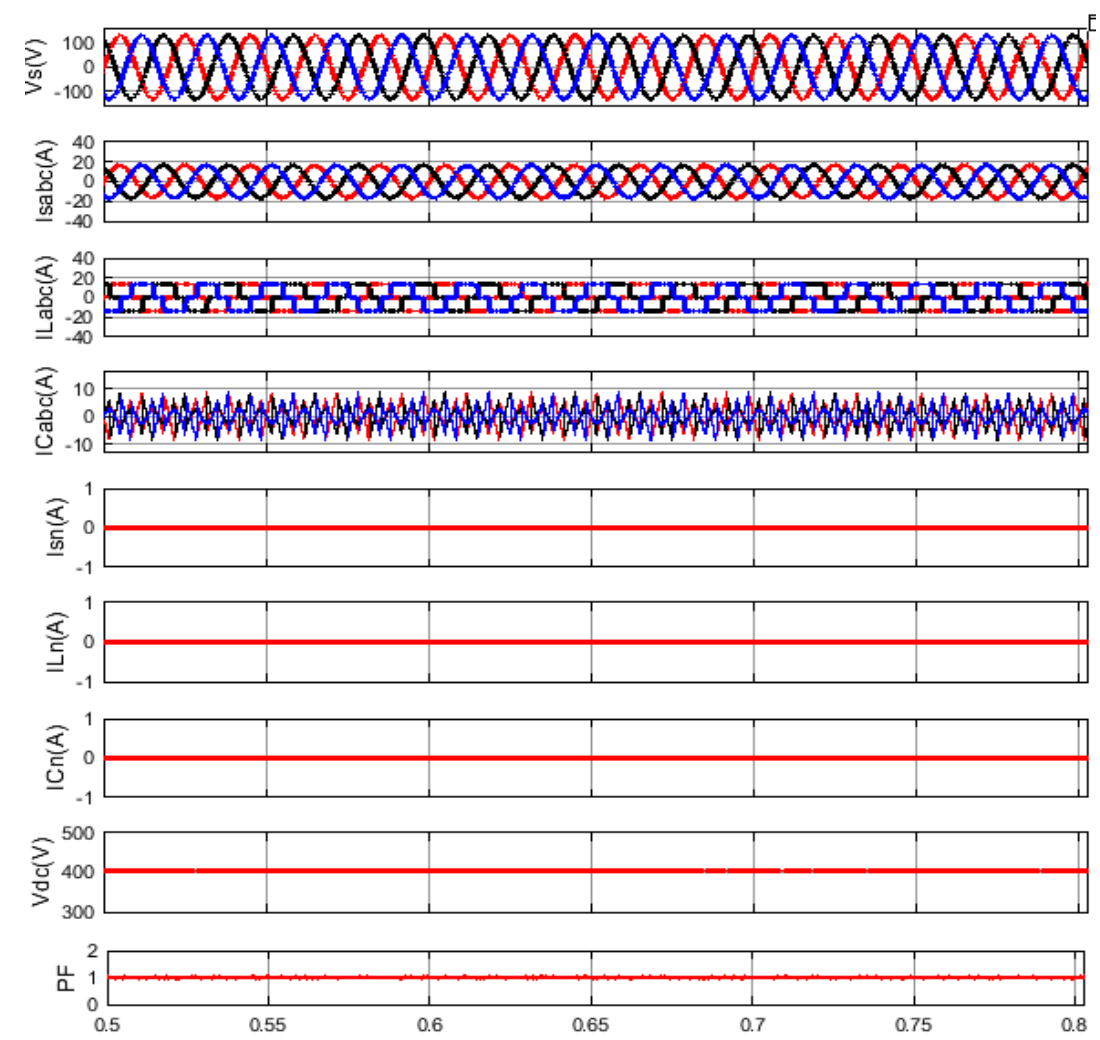

Figure 4. DSTATCOM behavior under balanced non-linear load condition
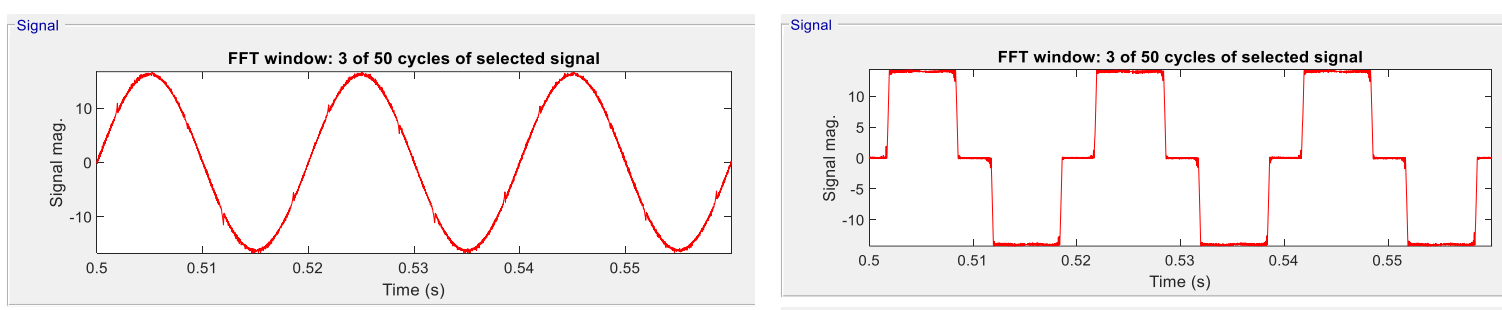

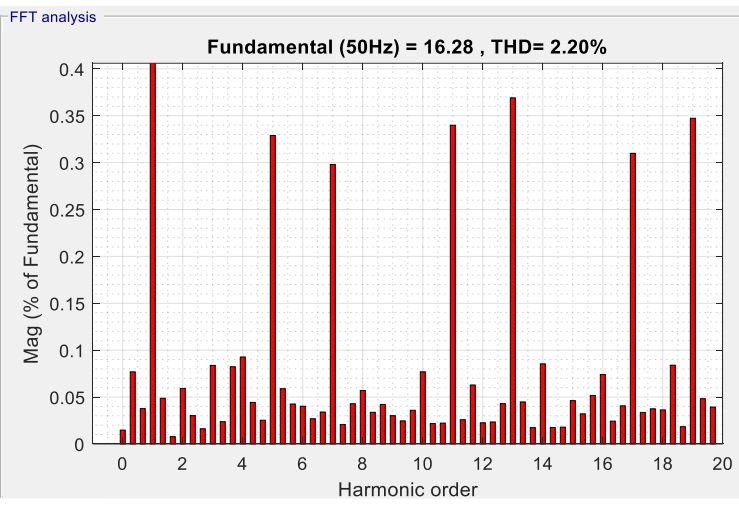

(a)

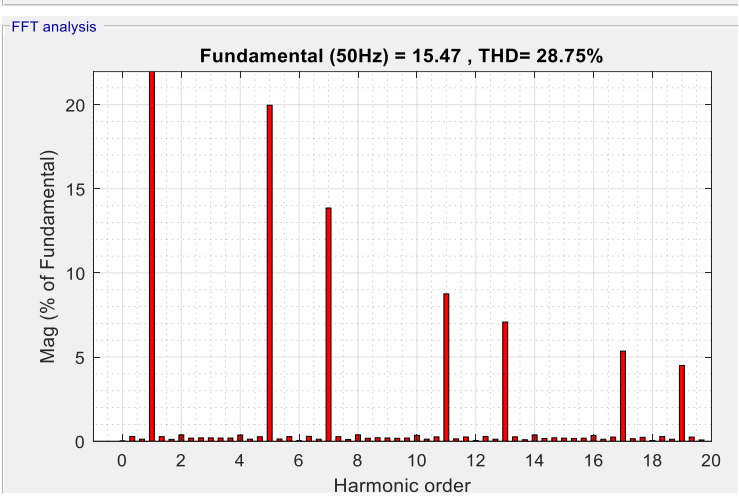

(b)

Figure 5. THD under balanced nonlinear load (a) source current, (b) load current

\subsection{DSTATCOM performance under dynamic condition}

The proposed controller is tested for linear as well nonlinear load variation to check the robustness of the controller under dynamic condition.

\subsubsection{Linear load variation}

DSTATCOM performance under dynamic state when the linear load $(4 \mathrm{kVA}, 0.8 \mathrm{pf})$ and nonlinear load ( $3 \mathrm{P} 4 \mathrm{~W}$ rectifier based non-linear load $\mathrm{R}=15 \Omega$ and $\mathrm{L}=100 \mathrm{mH}$ ) is added at 0.6 s to existing load is depicted in figure 6 in terms of PCC voltage $\left(V_{s}\right)$,source current $\left(I_{s a b c}\right)$,Load current $\left(I_{\text {Labc }}\right)$ 
source neutral current $\left(I_{S n}\right)$, load neutral current $\left(I_{L n}\right)$, compensator neutral current $\left(I_{C n}\right)$, DC link voltage $\left(V_{d c}\right)$ and power factor $(P F)$ respectively. The source current is increased with increasing load at $\mathrm{t}=0.6 \mathrm{~s}$ but remains balanced and sinusoidal with non-linear load and DC link voltage is also maintained constant at $400 \mathrm{~V}$. THD of source current $\left(I_{s a}\right)$ and load current $\left(I_{L a}\right)$ is depicted in figure $7(\mathrm{a}, \mathrm{b})$. The load current has THD $14.02 \%$ whereas source current $\quad$ only $1.21 \%$ THD which shows the DSTATCOM with adaptive control works efficiently for harmonics suppression for source current.

\subsubsection{Nonlinear load variation.}

\subsubsection{When one phase of load is out}

DSTATCOM performance under dynamic state with linear non-linear load(3P4W rectifier based non-linear load $R=15 \Omega$ and $L=100 \mathrm{mH}$ ) when a phase of the load is out at $t=0.6 \mathrm{~s}$ to $t=0.7 \mathrm{~s}$ of this load depicted in figure8 in terms of PCC voltage $\left(V_{s}\right)$,source current $\left(I_{s a b c}\right)$, Load current $\left(I_{L a b c}\right)$ source neutral current $\left(I_{S n}\right)$, load neutral current $\left(I_{L n}\right)$,compensator neutral current $\left(I_{C n}\right)$, DC link voltage $\left(V_{d c}\right)$ and source power factor $(P F)$ respectively. The source current is decreased when a phase load is out during above mentioned time duration, but it is remains balanced and sinusoidal with non-linear load and DC link voltage is also maintained constant at 400V. THD of source current $\left(I_{s a}\right)$ and load current $\left(I_{L a}\right)$ is depicted in figure 9(a,b). The load current has THD $28.60 \%$ whereas source current only $2.25 \%$ THD which shows the DSTATCOM with adaptive control works efficiently for source harmonics suppression under this condition also.

\subsubsection{When non-linear increased at $t=0.6 \mathrm{~s}$}

DSTATCOM performance under dynamic state when the nonlinear load (3P4W rectifier based non-linear load $\mathrm{R}=15 \Omega$ and $\mathrm{L}=100 \mathrm{mH}$ ) is added to existing non-linear load(3P4W rectifier based non-linear load $\mathrm{R}=15 \Omega$ and $\mathrm{L}=100 \mathrm{mH}$ ) at $0.6 \mathrm{~s}$ is depicted in figure10 in terms of PCC voltage $\left(V_{S}\right)$,source current $\left(I_{s a b c}\right)$,Load current $\left(I_{L a b c}\right)$ source neutral current $\left(I_{S n}\right)$, load neutral current $\left(I_{L n}\right)$,compensator neutral current $\left(I_{C n}\right)$, DC link voltage $\left(V_{d c}\right)$ and source power factor $(P F)$ respectively. The source current is increased with increasing load at $t=0.6 \mathrm{~s}$ but is remains balanced and sinusoidal with non-linear load and DC link voltage is also maintained constant at 400V. THD of source current $\left(I_{s a}\right)$ and load current $\left(I_{L a}\right)$ is depicted in figure $11(\mathrm{a}, \mathrm{b})$. The load current has THD $28.45 \%$ whereas source current only $2.52 \%$ THD which shows the DSTATCOM with adaptive control works efficiently for harmonics suppression under this condition also.

\subsubsection{When nonlinear is increased between two phases}

DSTATCOM performance under dynamic state when the nonlinear load (rectifier based single phase non-linear load $\mathrm{R}=15 \Omega$ and $\mathrm{L}=100 \mathrm{mH}$ ) is added to existing non-linear load(3P4W rectifier based three non-linear load $R=15 \Omega$ and $L=100 \mathrm{mH}$ ) is depicted in figure 12 in terms of PCC voltage $\left(V_{S}\right)$,source current $\left(I_{s a b c}\right)$,Load current $\left(I_{L a b c}\right)$ source neutral current $\left(I_{S n}\right)$, load neutral current $\left(I_{L n}\right)$,compensator neutral current $\left(I_{C n}\right)$, DC link voltage $\left(V_{d c}\right)$ and source power factor $(P F)$ respectively. The source current is increased with increasing load at $\mathrm{t}=0.6 \mathrm{~s}$ but is remains balanced and sinusoidal with non-linear load and DC link voltage is also maintained constant at 400V. THD of source current $\left(I_{s a}\right)$ and load current $\left(I_{L a}\right)$ is depicted in figure 13(a,b). The load current has THD 
$30.86 \%$ whereas source current only $4.67 \%$ THD which shows the DSTATCOM with adaptive control works efficiently for harmonics suppression under this condition also.

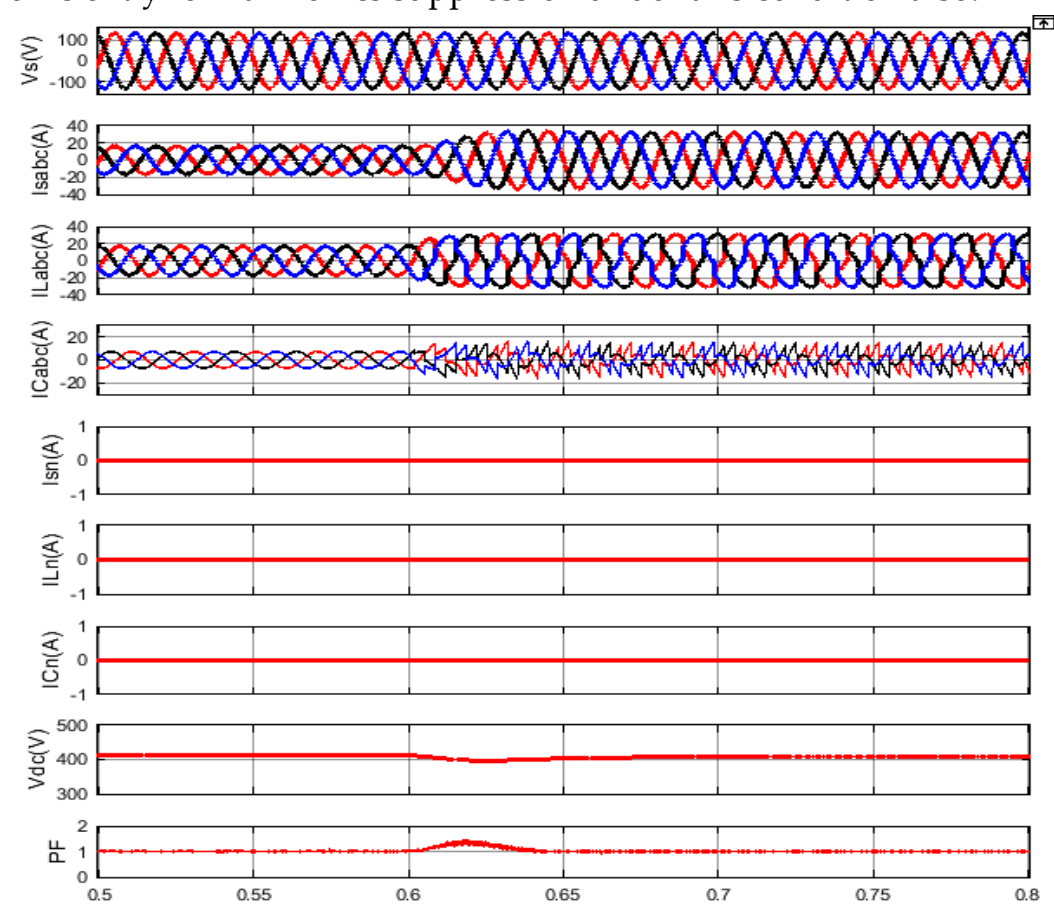

Figure 6. DSTATCOM behavior when nonlinear load (3P4W rectifier based nonlinear load $\mathrm{R}=15 \Omega$ and $\mathrm{L}=100 \mathrm{mH}$ at $\mathrm{t}=0.6 \mathrm{~s})$ is added to existing balanced ( $4 \mathrm{kVA}, 0.8 \mathrm{pf})$ linear load.
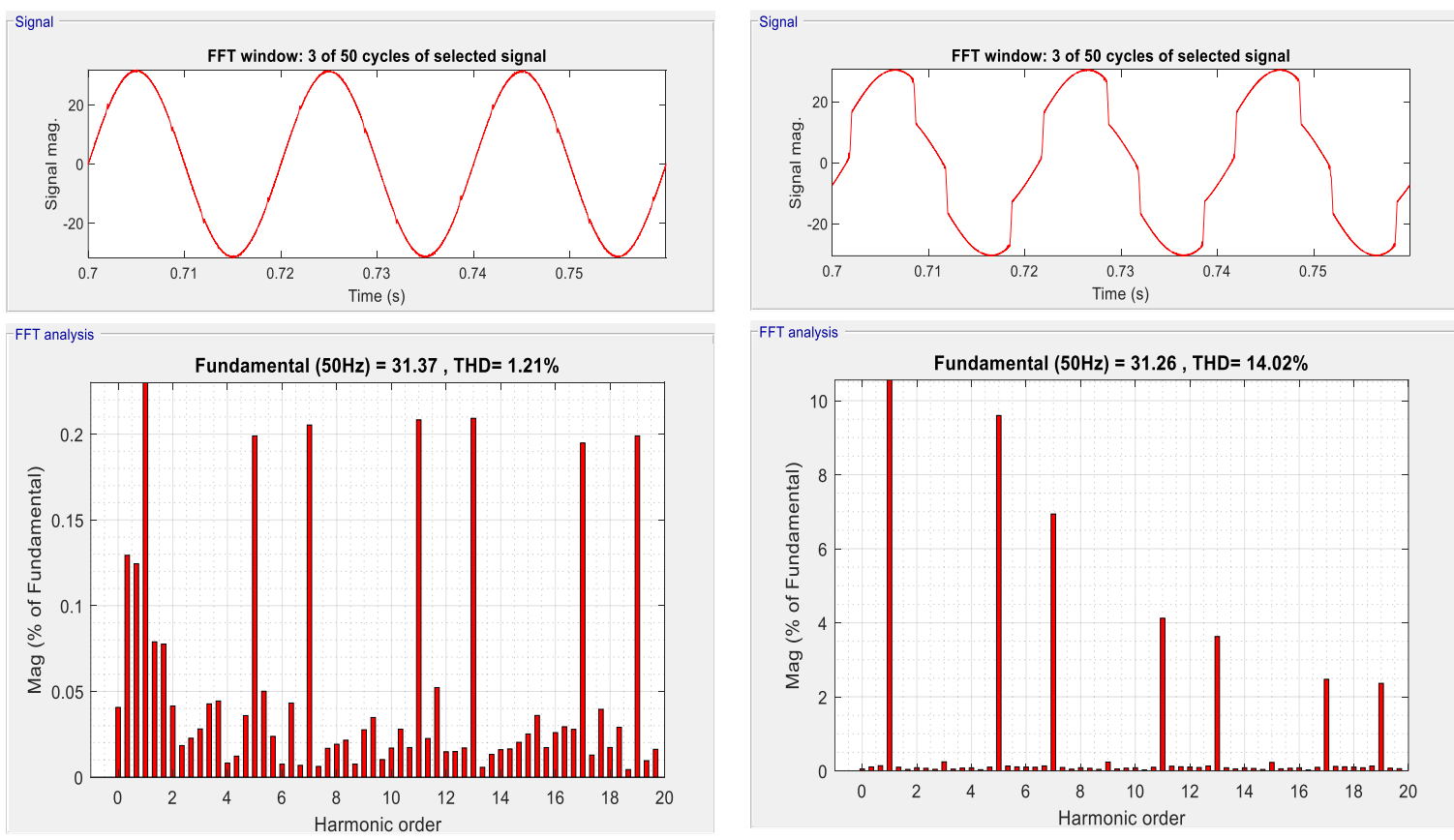

(a)

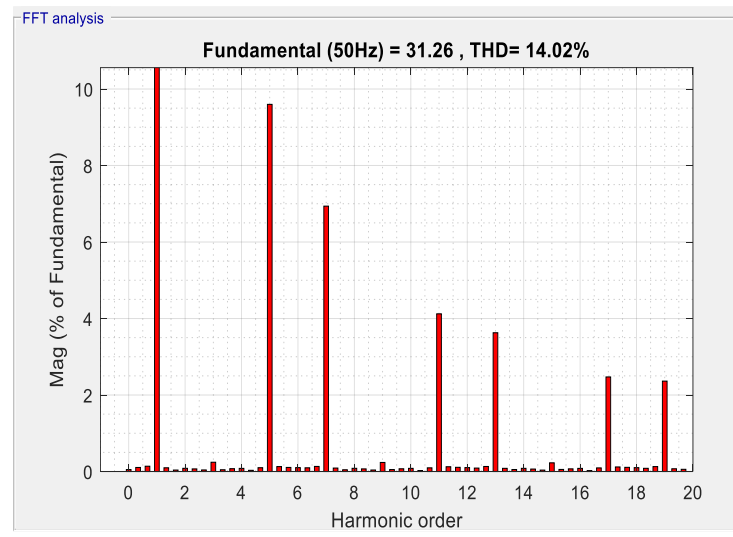

(b)

Figure 7. THD spectrum when nonlinear load (3P4W rectifier based non-linear load $R=15 \Omega$ and $L=100 \mathrm{mH}$ at $\mathrm{t}=0.6 \mathrm{~s}$ ) is added to existing balanced linear load (a) source current, (b) load current. 


\subsubsection{0u}
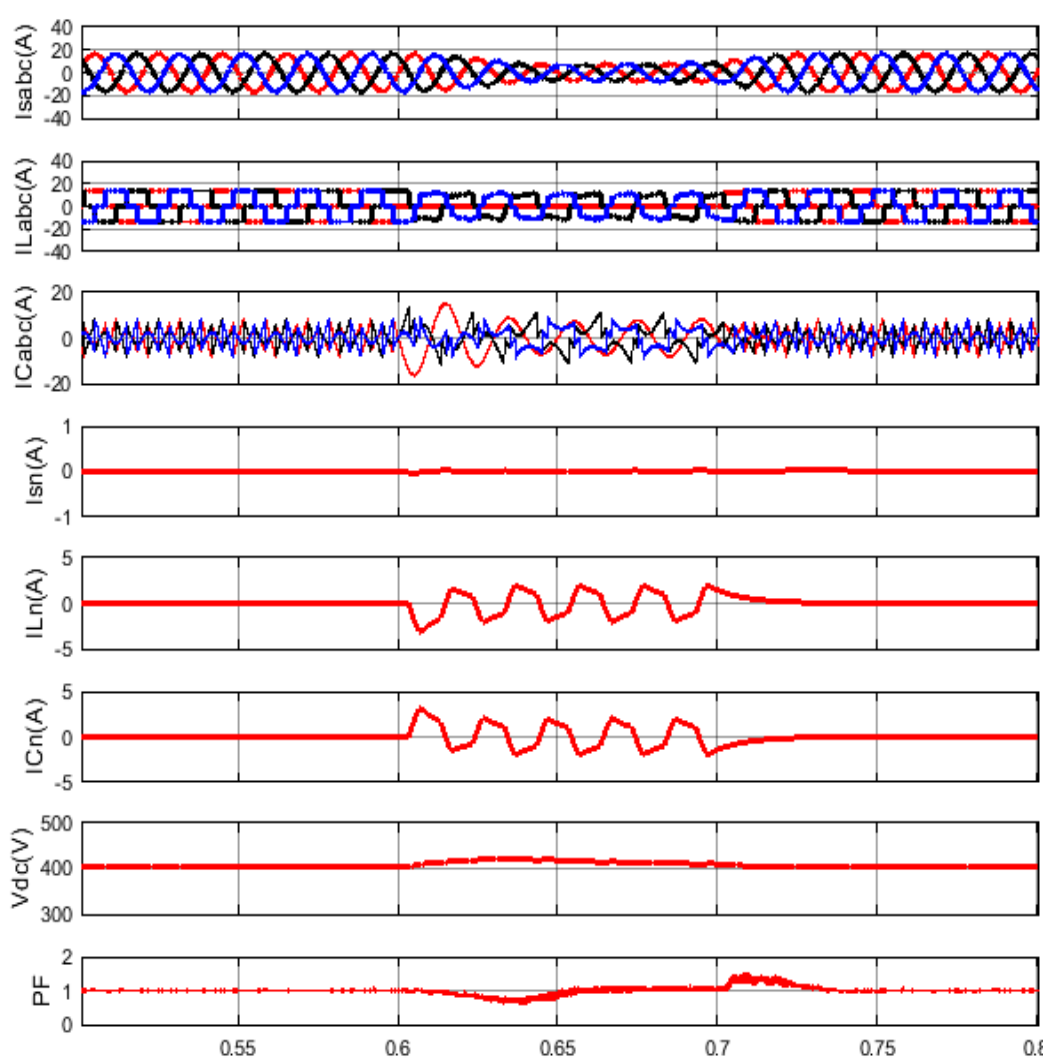

Figure 8. DSTATCOM behavior when one phase is out at $=0.6 \mathrm{~s}$ of nonlinear load (rectifier based non-linear load $\mathrm{R}=15 \Omega$ and $\mathrm{L}=100 \mathrm{mH}$ )
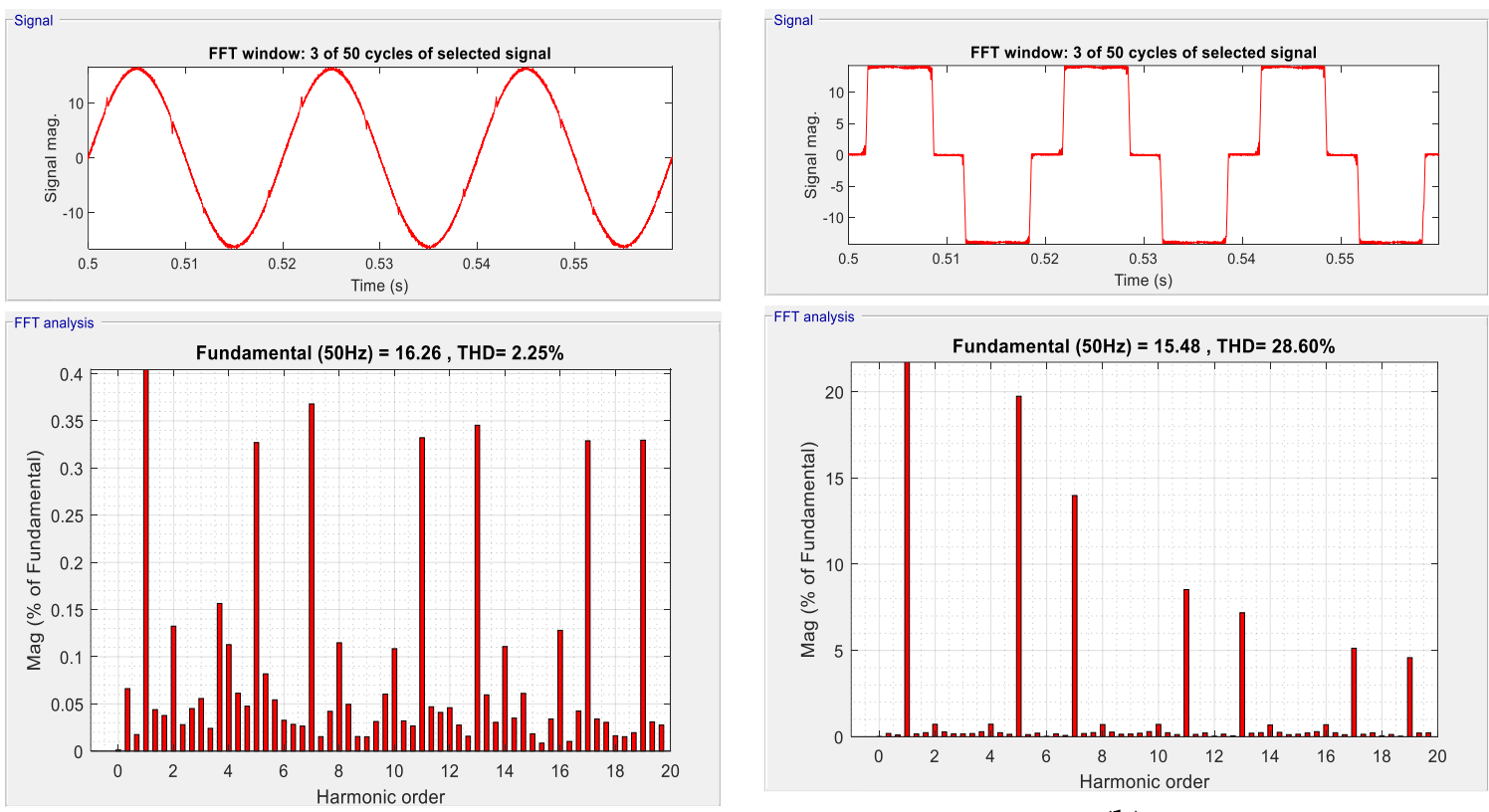

(a)

(b)

Figure 9. THD spectrum when one phase of nonlinear load (3P4W rectifier based non-linear load $R=15 \Omega$ and $\mathrm{L}=100 \mathrm{mH}$ at $\mathrm{t}=0.6 \mathrm{~s}$ ) is out (a) source current, (b) load current 


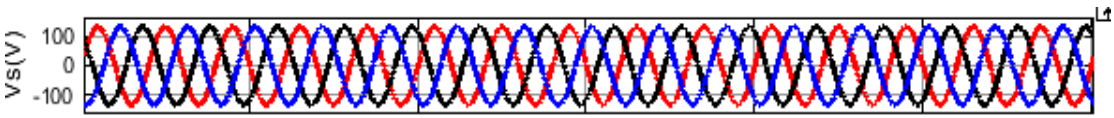
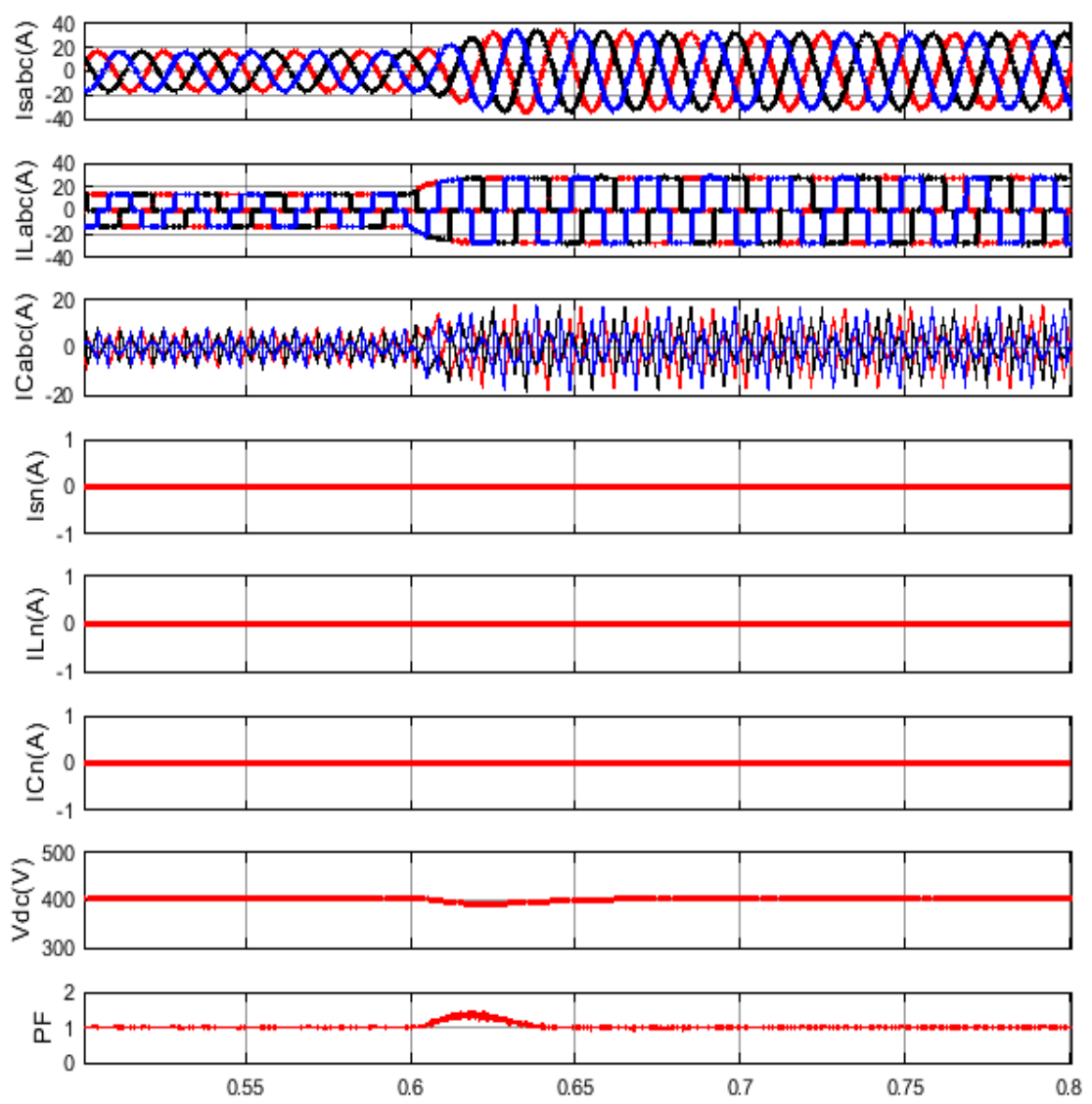

Figure 10. DSTATCOM behavior when nonlinear load (3P4W rectifier based non-linear load $R=15 \Omega$ and $\mathrm{L}=100 \mathrm{mH}$ at $\mathrm{t}=0.6 \mathrm{~s}$ ) is added to existing balanced nonlinear load (3P4W rectifier based non-linear load $\mathrm{R}=15 \Omega$ and $\mathrm{L}=100 \mathrm{mH})$.
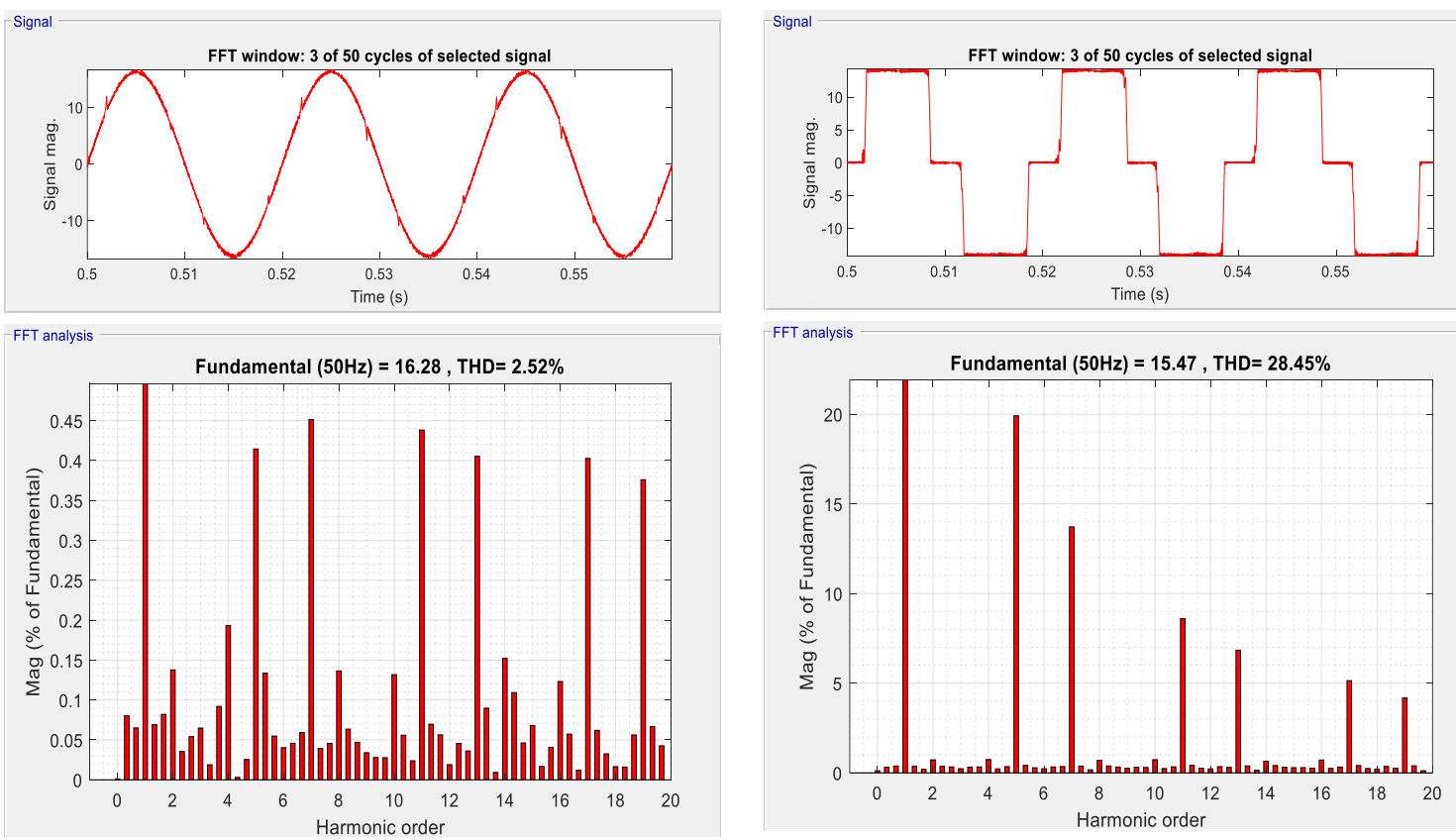

(a)

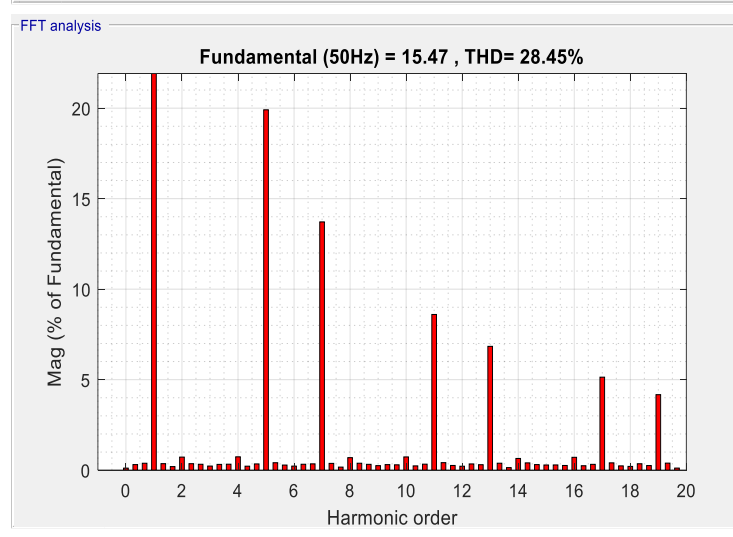

(b)

Figure 11. THD spectrum when nonlinear load ( $3 \mathrm{P} 4 \mathrm{~W}$ rectifier based non-linear load $\mathrm{R}=15 \Omega$ and $\mathrm{L}=100 \mathrm{mH}$ ) is added at $\mathrm{t}=0.6 \mathrm{~s}$ to existing nonlinear load ( $3 \mathrm{P} 4 \mathrm{~W}$ rectifier based non-linear load $\mathrm{R}=15 \Omega$ and $\mathrm{L}=100 \mathrm{mH}$ ) (a) source current, (b) load current 


\section{돈.m}
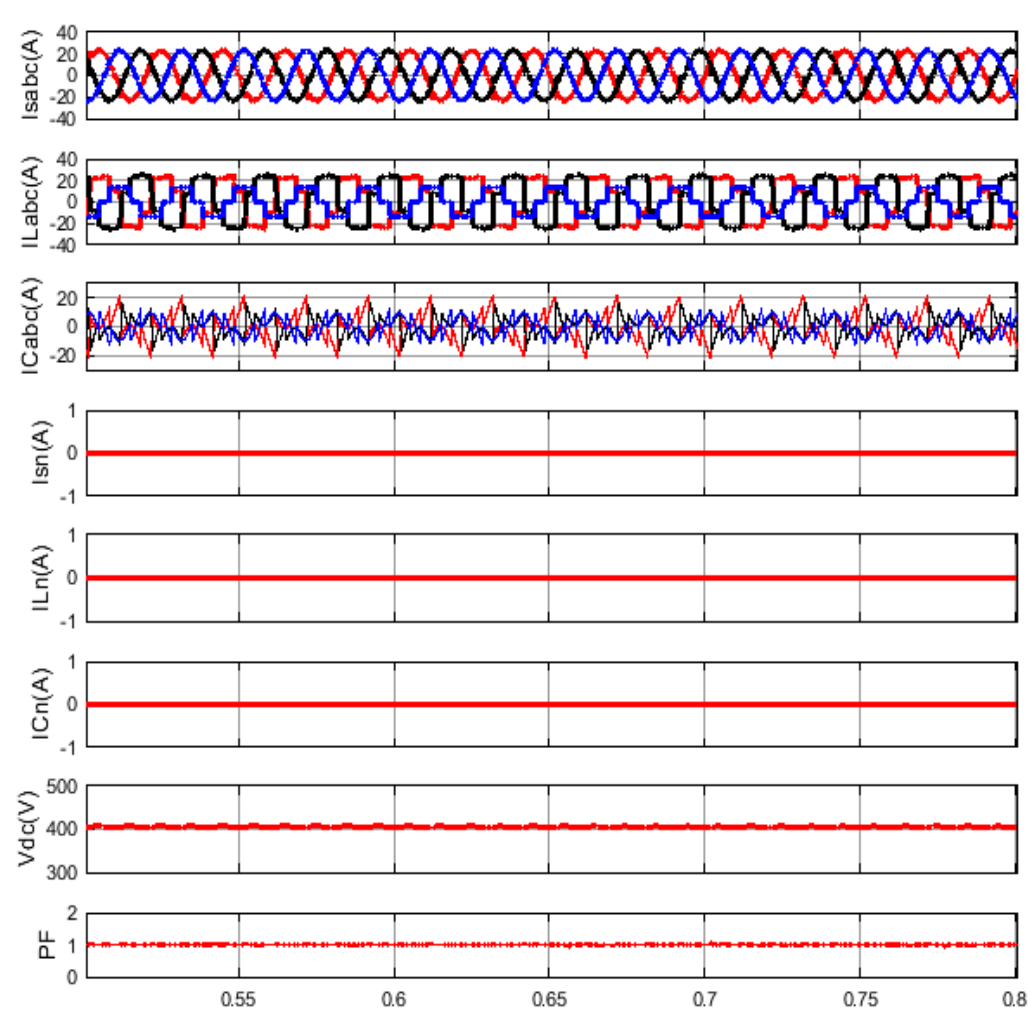

Figure 12. DSTATCOM behavior when nonlinear load (rectifier based single-phase non-linear load $R=15 \Omega$ and $\mathrm{L}=100 \mathrm{mH}$ ) is added to existing balanced nonlinear load (3P4W rectifier based non-linear load $\mathrm{R}=15 \Omega$ and $\mathrm{L}=100 \mathrm{mH}$ )
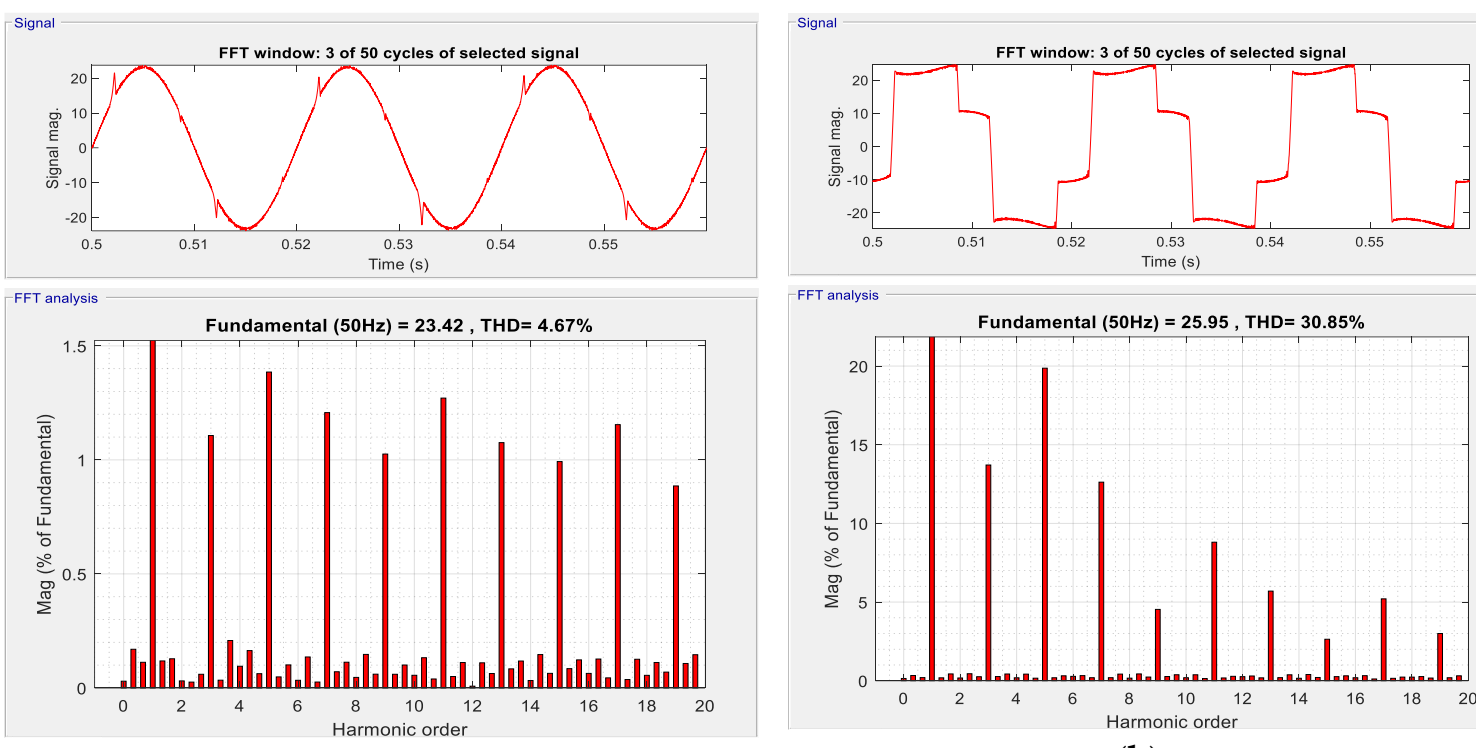

(a)

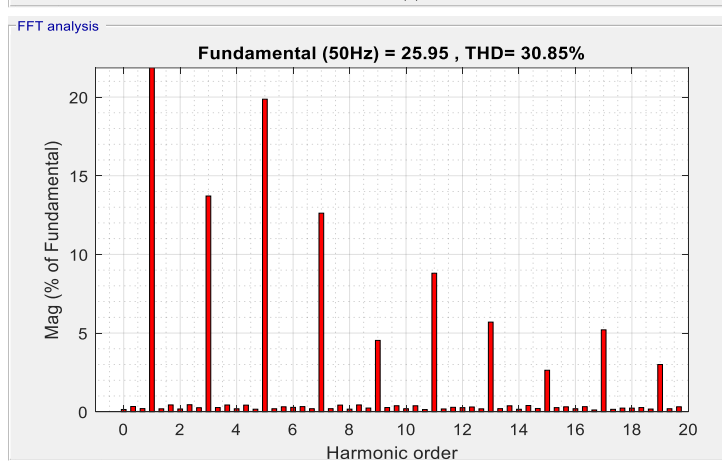

(b)

Figure 13. THD spectrum when nonlinear load (rectifier based single phase nonlinear load $R=15 \Omega$ and $L=100 \mathrm{mH}$ ) is added to existing nonlinear load ( $3 \mathrm{P} 4 \mathrm{~W}$ rectifier based nonlinear load $\mathrm{R}=15 \Omega$ and $\mathrm{L}=100 \mathrm{mH}$ ) (a) source current, (b) load current

\section{Conclusions}

The adaptive controller for DSATCOM is developed for power quality enhancement in 3phase 4wire distribution system. This control technique is simulated for variable linear/nonlinear load under steady state and dynamic conditions. It has been observed from the simulated results that the proposed controller is capable for harmonic suppression of the supply side current, load balancing, 
regulation of DC link voltage, neutral current compensation and power factor improvement under steady state as well as dynamic conditions. THD of source current in all cases implemented using adaptive controller is below IEEE standards. The proposed controller shall be assistance to engineering which are working in the distribution system for power quality enhancement.

\section{References}

1. Dugan RC,McGranaghan MF,BeatyHW, Electric power systems quality,2ed.New York:MCGraw Hill,2006.

2. IEEE Recommended Practices and requirement for Harmonic Control on electric power system,IEEE Std519,19992.

3. Choe GH, Park MH. A new injection method for AC harmonic elimination by active power filter. IEEE Trans Ind Electron 1988;35:141-147.

4. Akagi H, Atoh S, Nabae A. Compensation characteristics of active power filter using multi series voltage source PWM converters. Electrical Eng Jpn 1986;106:563-70.

5. Luo A, Shuai Z, Zhu W, Shen ZJ. Combined system for harmonic suppression and reactive power compensation. IEEE Trans Ind Electron 2009;56:418-28.

6. Wu T-F, Nien HS, Hsieh H-M, Shen CL. PV power injection and active power filtering with amplitudeclamping and amplitude scaling algorithms. IEEE Trans Ind Appl 2007;43:731, 741.

7. Singh B, Rajagopal V, Neural -network-based integrated electronic load controller for isolated asynchronous generators in small hydro- generation. IEEE Trans Ind Electron2011;58:4264-74.

8. He J,Li YW,Blaabjerg F,Wang X, Active harmonic filtering using current controlled grid -connected DG units with closed -loop power control.IEEE Trans Power Election 2014;29:642-53.

9. Green TC, Marks JH. Control techniques for active power filters. IEE Proc Electric Power Appl 2005;152:369-81.

10. Abdeslam DO, Wira P, Merckle J, Flieller D, Chapuis YA. A unified artificial neural network architecture for active power filters. IEEE Trans Ind Electron 2007;54:61-76.

11. Haykin S. Adaptive filter theory. New Delhi: Pearson Education Asia, 2011.

12. Chen $Y$, Kong $Q$, Qian H, Xing S. Shunt active power filter using average power and RLS self-adapting algorithms. In Proceedings of sixth international conference on intelligent systems design and applications, Vol. 2, 2006:25-30.

13. Bhim Singh, Sabha Raj Arya, Adaptive Control of Four-Leg VSC Based DSTATCOM in Distribution System. International Journal of Emerging Electric Power Systems 2014; 15(1): 93-99.

14. Ketabi A, Farshadnia M, Malekpour M, Feuillet R. A new control strategy for active power line conditioner using adaptive notch filter. J Electrical Power Energy Syst 2013; 47:31-40.

15. Jain S, Singh S, Singh J. An adaptive time-efficient technique for harmonics estimation of non-stationary signals. IEEE Trans Ind Electron 2013;60:3295-303.

16. Karimi H, Karimi Ghartemani M, Iravani MR, Bakhshai AR. An adaptive filter for synchronous extraction of harmonics and distortions. IEEE Trans Power Deliv 2003;18:1350-6.

17. Grino R, Cardoner R, Castello RC, Fossas E. Digital repetitive control of a three-phase four-wire shunt active filter. IEEE Trans Ind Electron 2007;54:1495-503

18. Sabha Raj Arya , Mittal M. Patel ,Sayed Javed Alam, Jayadeep Srikakolapu ,Ashutosh K. Giri ,Phase lock loop-based algorithms for DSTATCOM to mitigate load created power quality problems. Int Trans Electr Energ Syst. 2019;e12161. https://doi.org/10.1002/2050-7038.12161

19. Ashutosh K. Giri, Sabha Raj Arya , Rakesh Maurya , B. Chitti Babu, VCO-less PLL control-based voltagesource converter for power quality improvement in distributed generation system. IET Electr. Power Appl., 2019, Vol. 13 Iss. 8, pp. 1114-1124.

20. Ashutosh K. Giri, Sabha Raj Arya , Rakesh Maurya , B. Chittibabu, Control of VSC for enhancement of power quality in off-grid distributed power generation. IET Renew. Power Gener., 2020, Vol. 14 Iss. 5, pp. 771-778.

21. Sanjay Kumar Patel, Sabha Raj Arya, and Rakesh Maurya, Optimal Step LMS-Based Control Algorithm for DSTATCOM in Distribution System. Electric Power Components and Systems, 0(0): 1-17, 2019. ISSN: 15325008 print / 1532-5016 online DOI: 10.1080/15325008.2019.1602797

22. Manem Srinivas, Ikhlaq Hussain, and Bhim Singh, Combined LMS-LMF Based Control Algorithm of DSTATCOM for Power Quality Enhancement in Distribution System. IEEE Transactions on Industrial Electronic. DOI 10.1109/TIE.2016.2532278 
23. D. Chinna Kullay Reddy, S. Satya Narayana \& V. Ganesh, Towards an enhancement of power quality in the distribution system with the integration of BESS and FACTS device, International Journal of Ambient Energy, DOI: 10.1080/01430750.2019.1636866.

24. Mrutyunjaya Mangaraj, Anup Kumar Panda, DSTATCOM deploying CGBP based I $\cos \emptyset$ neural network technique for power conditioning. Ain Shams Engineering Journal xxx (2016) $x x x-x x x$. http://dx.doi.org/10.1016/j.asej.2016.11.009 2090-4479.

25. Prakash Chittora, Alka Singh \& Madhusudan Singh, Application of Hopfield Neural Network for Harmonic Current Estimation and Shunt Compensation. Electric Power Components and Systems, 46(3):290-301, 2018. ISSN: 1532-5008 print / 1532-5016 online DOI: 10.1080/15325008.2018.1445794. 